\title{
SOCIAL EMOTIONAL LEARNING AND MUSIC EDUCATION
}

\author{
M. Nevra KÜPANA ${ }^{1}$
}

\begin{abstract}
The purpose of this study is to show the relationship of music education and social emotional learning. In this regard, the relationship of music education and social emotional learning has been researched by literature review. The process of understanding and comprehending the social and emotional aspects of life are referred to as "social emotional learning". The components of social emotional learning are self-awareness, social awareness, responsible decision making, self-management and relationship skills. In a school setting, social and emotional learning includes the following skills: 1. effective relationship skills; 2. responsive, efficient and cooperative participation in group studies; 3 . control and conveying through proper means the feelings and impulses; 4 . solving the interpersonal conflicts and disputes in a non-violent, constructive, peaceful and thoughtful manner; 5. living the life with sound and correct personality traits; 6 . ability to incorporate learning, learning and reflective learning into every aspect of life. Music and social emotional learning complements each other in the education process with the following properties: a. Music can be used as an emotional stimulus; b. Music can be used as an aesthetic experience; c. Music can be used for relaxation and imagination; d. Making music can be a form of self expression; e. Making music can be a form of group experience. These skills can be developed by social emotional learning programs to be prepared according to the students' developmental periods. Such programs are also useful for cognitive skills. Activies such as improvisation, ensemble playing/ singing, defining emotions with music can be used in developing social emotional learning skills in music education. There is a significant relationship between teaching effectiveness and social emotional skills. Therefore, it is important to develop the knowledge and skills of the music teachers associated with social emotional learning.
\end{abstract} Keywords: social emotional learning, SEL, music education.

${ }^{1}$ Yrd. Doç. Dr., Sakarya Üniversitesi Devlet Konservartuvarı, Sakarya, nkupana(at)sakarya.edu.tr 


\title{
SOSYAL DUYGUSAL ÖĞRENME VE MÜZIK EĞiTiMi
}

\begin{abstract}
$\mathrm{Bu}$ çalışmanın amacı sosyal duygusal öğrenme ve müzik eğitimi ilişkisini ortaya koymaktır. $\mathrm{Bu}$ doğrultuda sosyal duygusal öğrenme ve müzik eğitimi ilişkisine yönelik literatür tarama çalışması yapılmıştır. Sosyal ve duygusal öğrenme yaşamın sosyal ve duygusal yönlerini anlama ve kavrama sürecidir. Sosyal duygusal öğrenmenin öğeleri özfarkındalık, özyönetim, sosyal farkındalık, ilişki becerileri ve sorumlu karar almadır. Okul ortamında sosyal duygusal öğrenme şu becerileri içerir: 1. Etkili iletişim becerileri; 2. Grup çalışmalarına istekli, etkin ve işbirlikçi katılm; 3. Duyguların ve dürtülerin denetimi ve uygun yollarla iletilmesi; 4. Kişilerarası çatışmaların ve anlaşmazlıkların şiddetten arınmış, yapıcı, barışçıl ve düşünceli biçimde çözümü; 5. Sağlam ve doğru kişilik özellikleriyle hayatı yaşama; 6 . Hayatın her alanına öğrenmeyi öğrenme ve yansıtmalı öğrenme yaklaşımını taşıma. Müzik eğitimi ve sosyal duygusal öğrenme birbirlerini şu özelliklerle tamamlamaktadır: a. Müzik duyusal bir uyaran olarak kullanılabilir; b. Müzik estetik bir deneyim olarak kullanılabilir; c. Müzik rahatlama ve imgeleme için kullanılabilir; d. Müzik yapma kendini ifade etmenin bir şekli olabilir; e. Müzik yapma grup deneyiminin bir şekli olabilir. Bu beceriler öğrencilerin gelişim dönemlerine uygun olarak hazırlanacak sosyal duygusal öğrenme programlarıyla geliştirilebilir. Doğaçlama, toplu çalma/söyleme, müziğe ilişkin duyguların tanımlanması gibi etkinliklerle müzik eğitiminde sosyal duygusal öğrenme becerileri geliştirilebilir. Sosyal duygusal beceriler ile öğretim etkililiği arasında anlamlı bir ilişki vardır. Müzik öğretmenlerinin yetiştirilmesinde onların sosyal duygusal öğrenmeye ilişkin bilgi ve becerilerinin geliştirilmesi önem taşımaktadır.
\end{abstract}

Anahtar Kelimeler: sosyal duygusal öğrenme, SEL, müzik eğitimi. 


\section{INTRODUCTION}

Social and emotional learning is an understanding and comprehension process of social and emotional aspects in life. This learning process consists of the following (Cohen, 200, s. 6; cited by: Türnüklü, 2004, s. 141):

To read, decode and understand the information of social and emotional fields in life,

To use information of social and emotional fields to resolve interpersonal problems encountered in social life,

To be a creative learner in social and emotional field of life.

Social emotional learning includes emotional intelligence, social intelligence and social-emotional competences (Arslan \& Akın, 2013, s. 27). The first study conducted on competency of people in social skills and emotion management skills is considered to be the model "Multiple Intelligences" developed by Howard Gardner (1983) and the "interpersonal intelligence" and "intrapersonal intelligence" dimensions in this model. Interpersonal intelligence emphasizes understanding other people and cooperating with them while intrapersonal intelligence emphasizes understanding and knowing oneself (Türnüklü, 2004, s. 139; Jacobi, 2012, s. 73). Salovey and Mayer (1990) put forward the concept of emotional intelligence (Goleman, 2012, s. 11) and explained it as the skill of perceiving, assessing and expressing emotions accurately, generating and accessing to emotions which facilitate thinking, understanding emotions and information related to emotions, controlling emotions which lead to emotional and intellectual development (Türnüklü, 2004, s. 139). Goleman (2012, s. 15) ranges fundamental factors of emotional intelligence as; self-conscience, self-control, social conscience and relationship management skills.

Salovey and Gardner collect emotional intelligence skills under the following titles (Goleman, 2012, s. 73):

Self-conscience: Self-knowledge -recognizing a feeling as soon as sets- basis of the emotional intelligence.

Managing emotions: It consists of self-appeasement, skill of avoiding intense anxieties, pessimism and sensitivity. 
Motivating oneself: Self-motivation by means of gathering emotions in line with a certain purpose and emotional self-control is required for productivity and creativity.

Recognizing emotions in others: The fundamental skill in relationship with people is empathy.

Handling relationships: The art of relationship is the skill of managing emotions in others.

Emotional intelligence starts to develop at the first years of life. The first grounds of it are laid by early period of childhood within parent and immediate family environment. The period between 10th and 18th month is critical for the formation of emotional conscience. A child recognizes acceptance and rejection conditions of emotions through parents' reactions to emotions and knows his/her own emotions. In this way, emotions find opportunity to develop in child's common life with immediate environment and to have a sound ground (Baltaş, 2005, s. 8).

First ideas on emotional intelligence include factors of social intelligence as well (Goleman, 2007, s. 108). Making a distinction between personal and social skills, Goleman (2007, s. 108) explains elements which form social intelligence in two categories; social awareness and social skills. Accordingly, social awareness consists of the following components:

Primal empathy: Sharing feelings of other people and reading non-verbal emotional signs

Attunement: Deep listening, being attuned to a person

Empathetic accuracy: Understanding ideas, feelings and intentions of another person

Social cognition: Knowing how social world functions

Social skill consists of the following components (Goleman, 2007, s. 108):

Synchrony: Smooth interaction at non-verbal level

Self-presentation: Introducing oneself effectively

Influence: Having impact on the consequence of social interactions 
Concern: Caring for needs of other people and acting in line with those needs

Many children come to school with competency in emotional and social skills acquired in their family while many of those are lack of skills such as selfexpression, expressing demands and emotions, coping with intense feelings, anger management, listening, sharing and cooperation when they come to school. These social skills and emotion management skills which could not be acquired in family may result in interpersonal conflicts and disagreements. Therefore, acquiring social and emotional skills in school environment is important. In this way, a person will have acquired competency not only in cognitive field but also in social skills and emotion management skills which are the basis of human relationship when they complete their education. It is a must to acquire social and emotional skills which are regarded to be among fundamental conditions for living in effective, balanced, peaceful, happy and harmonized way in social life (Türnüklü, 2004, s. 142).

Elias, Arnold and Hussey (2003) explain emotional intelligence as a social and emotional skills system which turns cognitive activities into action and success. They associate emotional intelligence field with skill field of emotional and social learning in school environment. Social and emotional competency field in classroom and school environment includes the following skills (cited by: Türnüklü; 2004, s. 141):

Effective communication skills,

Willing, efficient and cooperative participation to group activities,

Control of emotions and impulses and transmitting them via appropriate ways,

Resolution of interpersonal conflicts and disagreements in non-violent, constructive, peaceful and mindful ways,

Living life with sound and correct personality traits

Learning how to learn in every field of life and having the approach of reflective learning.

Social and emotional learning consists of processes on acquiring and effective application of information, skills and attitudes which are required to understand and manage emotions of children and adults, reach positive aims, fell 
emotions of other people and show empathy, establish and maintain positive relationships and take responsible decisions. These interpersonal and intrapersonal competencies can be thought and measured. Research show that students with these skills are more successful in their school and personal lives (CASEL, 2013, s. 4). Social emotional learning skills are very effective on students in terms of academic success, learning process motivation, increase in interest to school, active participation to cooperation process, standing out social skills and developing problem solving skills (Arslan, Akın, \& Demir, 2012). An effective social emotional learning program starts in pre-school period and lasts until the end of high school education. CASEL defines five interrelated competency fields in cognitive, affective and behavioral terms. Definitions of these five competencies are as follows (CASEL, 2013, s. 9):

Self-awareness: It is the ability to accurately recognize one's emotions and thoughts and their influence on behavior. This includes accurately assessing one's strengths and limitations and possessing a well-grounded sense of confidence and optimism.

Self-management: It is the ability to regulate one's emotions, thoughts, and behaviors effectively in different situations. This includes stress management, impulse control, motivating oneself and working towards achieving personal and academic goals.

Social awareness: It is the ability to take the perspective of and empathize with others from diverse backgrounds and cultures, to understand social and ethical norms for behavior, and to recognize family, school, and community resource.

Relationship skills: It is the ability to establish and maintain healthy and rewarding relationships with diverse individuals and groups. This includes clear communication, active listening, cooperation, resisting inappropriate social pressure, constructive negotiation, seeking and offering help when needed.

Responsible decision making: It is the ability to make constructive and respectful choices about personal behavior and social interactions based on consideration of ethical standards, safety concerns, social norms, the realistic evaluation of consequences of various actions, and the well-being of self and others.

A social and emotional program should be drawn for each age-group in order to develop students' social and emotional learning in school environment. The themes to be included in this program are presented in the following table (Türnüklü, 2004, s. 147): 
Table 1. Themes of Social and Emotional Learning Program

\begin{tabular}{|c|c|c|}
\hline Developing self-respect & $\begin{array}{l}\text { Recognizing and accepting one's } \\
\text { mistake } \\
\text { Being well-groomed } \\
\text { Self-criticism } \\
\text { Self-control } \\
\text { Accepting criticism }\end{array}$ & $\begin{array}{l}\text { Positive thinking } \\
\text { Positive self- perception } \\
\text { Self-rewarding } \\
\text { Complimenting }\end{array}$ \\
\hline Emotion management skills & $\begin{array}{l}\text { Knowing emotions } \\
\text { Recognizing emotions } \\
\text { Expressing emotions } \\
\text { Managing emotions } \\
\text { Understanding emotions of others }\end{array}$ & $\begin{array}{l}\text { Empathy } \\
\text { Using I-language } \\
\text { Coping with fear } \\
\text { Coping with anger }\end{array}$ \\
\hline $\begin{array}{l}\text { Skills of coping with } \\
\text { undesirable situations }\end{array}$ & $\begin{array}{l}\text { Coping with mockery } \\
\text { Coping with anxiety } \\
\text { Coping with being excluded from a } \\
\text { group } \\
\text { Coping with peer pressure }\end{array}$ & $\begin{array}{l}\text { Coping with embarrassing } \\
\text { situations } \\
\text { Being aware of prejudices } \\
\text { Coping with failure }\end{array}$ \\
\hline Communication skills & $\begin{array}{l}\text { Understanding non-verbal } \\
\text { communication stimulators } \\
\text { Sending and understanding } \\
\text { messages }\end{array}$ & $\begin{array}{l}\text { Using I-language effectively } \\
\text { Active listening }\end{array}$ \\
\hline Conflict resolution skills & $\begin{array}{l}\text { Problem resolution skills in } \\
\text { interpersonal conflicts and } \\
\text { disagreements } \\
\text { Reconciliation }\end{array}$ & $\begin{array}{l}\text { Expressing demands } \\
\text { constructively } \\
\text { Peer peacemaking } \\
\text { Assertiveness }\end{array}$ \\
\hline Developing friendships & $\begin{array}{l}\text { Knowing oneself and others } \\
\text { Recognizing positive, strong and } \\
\text { skillful aspects of others } \\
\text { Respect to others' rights } \\
\text { Respect to personal values } \\
\text { Understanding body language } \\
\text { expression }\end{array}$ & $\begin{array}{l}\text { Accepting individual } \\
\text { differences } \\
\text { Accepting intersexual } \\
\text { differences } \\
\text { Assisting and asking for help }\end{array}$ \\
\hline $\begin{array}{l}\text { Skills of establishing and } \\
\text { maintaining relationship }\end{array}$ & $\begin{array}{l}\text { Keeping secret } \\
\text { Greeting } \\
\text { Being independent } \\
\text { Ability to say no } \\
\text { Asking permission/apologizing } \\
\text { Ability to have friends } \\
\text { Sharing-thanking } \\
\end{array}$ & $\begin{array}{l}\text { Establishing and maintaining } \\
\text { positive relationships with } \\
\text { people with different sexes, } \\
\text { background and religion } \\
\text { Being patient } \\
\text { Being included in a group }\end{array}$ \\
\hline
\end{tabular}




\begin{tabular}{|l|l|l|}
\hline Listening and working skills & $\begin{array}{l}\text { Skills of listening and } \\
\text { understanding } \\
\text { Effective listening during learning } \\
\text { Gathering attention and } \\
\text { concentrating } \\
\text { Effective use of time }\end{array}$ & $\begin{array}{l}\text { Setting a goal and making plan } \\
\text { Being willing to resolve } \\
\text { academic problems } \\
\text { Effective working habits }\end{array}$ \\
\hline Career planning & $\begin{array}{l}\text { Recognizing interest and skills } \\
\text { Recognizing learning strategies } \\
\text { Making decisions }\end{array}$ & $\begin{array}{l}\text { Recognizing occupational } \\
\text { interest } \\
\text { Choice of profession }\end{array}$ \\
\hline Values and attitudes & $\begin{array}{l}\text { Cooperation } \\
\text { Self-acceptance } \\
\text { Respect } \\
\text { Love } \\
\text { Tolerance } \\
\text { Creativity } \\
\text { Responsibility } \\
\text { Self-respect } \\
\text { Honesty } \\
\text { Feeling oneself sufficient }\end{array}$ & $\begin{array}{l}\text { Willingness to develop } \\
\text { Being helpful } \\
\text { Being merciful and } \\
\text { compassionate } \\
\text { Being willing to resolve } \\
\text { interpersonal conflicts } \\
\text { constructively } \\
\text { Being fair } \\
\text { Being peaceful } \\
\text { Being sensitive }\end{array}$ \\
\hline
\end{tabular}

Effective teaching methods are active, participatory and interesting for social emotional learning skill. Some examples are presented below (CASEL, 2013, s. 10):

It can be taught to little children how to define their own feelings and possible feelings of other people by means of modeling and coaching. To inspire and steer students by establishing a dialogue in case of a conflict resolution can be an effective method.

Students can make activity in intragroup decision making and regulating classroom rules in class meetings.

Students can learn cooperation and team work by taking part in team games.

Students can deepen their perception on current or historical event by means of questions based on problem resolution model.

Cross age guide (matching a student in early age with an older student) can be effective in building self-confidence, sense of belonging and developing academic skills. 
Matching is an effective tool to teach reflective listening.

\section{Music Education and Social Emotional Learning}

Music supports cognitive, psychomotor, lingual, social, emotional, communication and awareness skills, aesthetic aspect and creativity of children (Şahin, 2006, s. 82). Researchers report that music has impacts on social and emotional maturation of a person, autocontrol, work sharing and self-expression skills (Özmenteş, 2005, s. 3). Music lectures are the most ideal environment for the development of social emotional learning (Jacobi, 2012, s. 68). Music education and social emotional learning naturally complete each other. Common features of music training and social emotional learning are as follows (Pellitteri, 2006, s. 185; Edgar, 2013, s. 30):

a. Music can be used as a sensorial stimulator. Previously recorded music can be listened and its emotional features can be discussed. This activity can be used to develop students' vocabulary of emotions and skills on discussion their emotions.

b. Music can be used as an aesthetic experience. This experience can be expressed as an interaction between concerns about perception, sense, imagination and knowing, understanding and feeling. This interaction enable students to explore their inner world, establish consistent connections with works of art and develop new perceptions towards oneself and the world.

c. Music can be used for relaxing and imaging. Slow and relaxing music can decrease tense emotions of students and thus emotional arrangement can be ensured.

d. Making music can be a way of self-expression. The act of making music not only refers to self-expression but also has a therapeutic effect to relax inner tensions.

e. Making music can be a way of group experience. Making music collectively strengths ties between musicians.

The objective of social emotional learning is to acquire social emotional competency and safety on self-awareness, self-management, social awareness, relationship management and responsible decision making. Samples from music training field for each component are presented below (Edgar, 2013, s. 29):

Self-awareness: An independent student who tries to play a passage accurately. However, s/he believes that $\mathrm{s} /$ he will not succeed it and feels angry. If 
the student is aware of this emotion, s/he will express it and realize that this emotion will lead to negative and unrealistic opinions.

Self-management: If the student who was very angry before the first solo performance can realize his/her fear and its negative effects on his/her performance, $\mathrm{s} /$ he will learn how to take a deep breath, control heart pulses and relax for a better performance.

Social awareness: A group leader in a music community realizes that a beginner student exhibits a better performance and works more efficiently than an experienced student when $\mathrm{s} /$ he receives positive and constructive criticism rather than negative one.

Relationship management: An experienced student feels annoyed for not having been elected as group leader of a music community. Instead of developing a grudge, s/he talks about her/his disappointment with her/his chief and asks about another leadership position.

Responsible decision making: A student who is preparing for the examination of music department prepares a meticulous working programme.

Social skill is a prerequisite for many aims of music training. Various musical aims and required prerequisites are presented in the following table (Jacobi, 2012, s. 72):

Table 2. Prerequisites Required to Achieve Musical Aims

\begin{tabular}{|c|l|}
\hline Musical Aim & Prerequisite \\
\hline $\begin{array}{c}\text { Students listen to various music types and } \\
\text { other music which represent different cultures with } \\
\text { an open and accepting mind. }\end{array}$ & $\begin{array}{l}\text { Students should accept not only differences in } \\
\text { music tastes but also accept and adopt what is } \\
\text { different than them. }\end{array}$ \\
\hline $\begin{array}{c}\text { Students exhibit rehearsal or performance } \\
\text { skills in a musical community. }\end{array}$ & $\begin{array}{l}\text { Students should know others' turn, how to } \\
\text { listen to others and how to be tolerant and } \\
\text { respectful for others. }\end{array}$ \\
\hline $\begin{array}{c}\text { Students cooperate to compose a music piece } \\
\text { or to improvise. }\end{array}$ & $\begin{array}{l}\text { Students should perceive that each person's } \\
\text { ideas are valuable and understand each piece is } \\
\text { necessary to complete the whole and accept that } \\
\text { each person is unique in contribution. }\end{array}$ \\
\hline
\end{tabular}

Friendship is an important factor to learn social concepts and skills. Playing makes children acquire many skills about social development such as helping, 
sharing, respecting others' rights, obeying rules etc. (Güngör, 2003, s. 123). In addition, children learn controlling their emotional reactions, self-confidence, empathy and various moods and reactions in emotional development process of game. Orff considers improvisation as playing with an instrument. Considering each society to take its source from cultural values, Orff-Schulwerk creates playing areas where people can express oneself safely. In this safety environment, people socialize by means of using communication skills (Çimşir, 2013, s. 43).

Music activities which apply components of social emotional learning can be used in general music training, music communities, orchestra, taste training, music theory and other musical processes. Various activities for social emotional learning in music training are presented below (Pellitteri, 2006, s. 185; Edgar, 2013, s. 31):

Improvisation: The act of making music spontaneously, it combines the expression of current emotions with musical performance.

Collective playing/singing: Making music collectively is a way of social awareness. Students' learning how to be managed by a common beat is a way of impulse control. In addition, inclusion of solos in community brings opportunity to ensure autocontrol.

Definition of emotions related to music: Activities such as to determine, define emotions of characters in songs and empathize with them, determine and define moods related to musical pieces can be used.

There is a significant relationship between social emotional skills and teaching effectiveness (Hamann, Lineburg \& Paul, 1998, s. 87). Strong teacherstudent relationships are important in music training. The competency of teacher has a significant role to determine social and emotional needs of students (Edgar, 2013, s. 30).

\section{CONCLUSION AND DISCUSSION}

Social emotional learning includes the whole of emotional intelligence, social intelligence and social-emotional competencies (Arslan \& Akın, 2013, s. 27). Musical experiences develop emotional intelligence by means of the acquisition of skills related to accurate perception, assessment and expression of emotions, generating and accessing to emotions which facilitate to express and think, understanding emotions and information related to emotions, controlling emotions which lead to emotional and intellectual development while these experiences develop social intelligence by means of the acquisition of empathy, social cognition, 
social interaction, self-presentation and concern skills. Therefore, music training has an important role to acquire social and emotional competencies.

The objective of social emotional learning is to acquire social emotional competency and safety on self-awareness, self-management, social awareness, relationship management and responsible decision making. Music and social emotional learning complete each other in training process. Activities such as improvisation, collective playing and singing, defining emotions related to music have positive effects on social emotional learning.

There is a significant relationship between social emotional skills and teaching effectiveness (Hamann, Lineburg \& Paul, 1998, s. 87). Therefore, it is important to develop knowledge and skills of music teachers on social emotional learning during their education. In order to improve teaching effectiveness of preservice music teachers, opportunities which will develop social emotional skills should be included in curriculum. According to research, there is a correlation between social interaction and communication levels of people and their empathy skills and performances (Hançer \& Tanrısevdi, 2003, s. 216). According to Juchniewicz (2010, s. 288), approaches such as learning and developing non-verbal communication skills, knowing, accepting, focusing on prediction of student behaviors can develop social interaction skills of pre-service music teachers.

In many countries, social emotional learning program (SEL) functions as an organizing umbrella which gathers other programs such as character training, preventing violence, taking precautions against drugs and school discipline. It is scientifically proven that SEL which is applied for students from pre-school to the end of high school improves self-conscience and self-confidence of children, increases levels of empathy and control of disturbing emotions and impulses and it is useful for academic success (Goleman, 2012, s. 9). Music should be used to develop social emotional learning. Themes related to social emotional learning program (improving self-respect, emotion management skills, skills of coping with undesirable situation, communication skills, conflict resolution skills, developing friendships, skills of establishing and maintaining relationships, listening and working skills, career planning, values and attitudes etc.) can take place in music training process. In addition, it is recommended that qualitative and quantitative research should be conducted on social emotional in music training. 


\section{REFERENCES}

Arslan, S., \& Akın, A. (2013). Social emotional learning scale: The study of validity and reliability. Sakarya Üniversitesi Eğitim Fakültesi Dergisi, 25, 23-34.

Arslan, S., Akın, A. \& Demir, S. (2012). The validity and reliability of the Turkish Version of Social-Emotional Learning Scale (SELS). International Conferences on New Horizons in Education, CzechRepublic.

Baltaş, Z. (2005). Duygusal zeka (6. bask1). İstanbul: Remzi.

CASEL (2013). Effective social and emotional learning programs (Preschool and elementary school edition). www.casel.org adresinden 13 Aralı 2013 tarihinde edinilmiştir.

Cohen, J. (2001). Social and emotional education: Core concepts and practices. In Cohen, J (Ed.), Caring classrooms/intelligent schools: The social emotional education of young children (pp. 309-330). New York: Teachers College Press.

Çimşir, Ö. (2013). Eğitmen eğitimi ve iletişim. K. O. Koçak ve N. Lasio (Ed.), Türkiye'de müzik, oyun ve dans üzerine makaleler içinde (s. 37-44). Ankara: Müzik Eğitimi.

Edgar, S. N. (2013). Introducing social emotional learning to music eduction professional development. Update: Applications of Research in Music Education, 31(2), 28-36.

Elias, M., Arnold, H., \& Hussey, C. S. (2003). Introduction: EQ, IQ, and effective learning and citizenship. In M. Elias, H. Arnold, \& C. S. Hussey (Eds.), $E Q+I Q=$ best leadership practices for caring and successful schools (pp. 3-10). Thousand Oaks, CA: Corwin Press.

Goleman, D. (2007). Sosyal zeka: Insan ilişkilerinin yeni bilimi (3. bask1). İstanbul: Varlik. 
Goleman, D. (2012). Duygusal zeka: EQ neden IQ'dan önemlidir? (35. bask1). İstanbul: Varlık.

Güngör, A. (2003). Toplumsal ve duygusal gelişim. A. Ulusoy (Ed.), Gelişim ve öğrenme içinde (s. 93-124). Ankara: Anı.

Hamann, D.L., Lineburgh, N. ve Paul, S. (1998). Teaching effectiveness and social skill development. Journal of Research in Music Education, 46(1), 87-101.

Hançer, M. ve Tanrısevdi, A. (2003). Sosyal zeka kavramının bir boyutu olarak empati ve performans üzerine bir inceleme. C. $\ddot{U}$. Sosyal Bilimler Dergisi, 27(2), 211-225.

Jacobi, B. S. (2012). Opportunities for socioemotional learning in music classrooms. Music Educators Journal, 99, 68-74.

Juchniewicz, J. (2010). The influence of social intelligence on effective music teaching. Journal of Research in Music Education, 58, 276-293.

Özmenteş, S. (2005). Müzik eğitiminin boyutları ve çalgı eğitimi. İönü Üniversitesi Ĕ̈itim Fakültesi Dergisi, 9, 89-99.

Pellitteri, J. S. (2006). The use of music in facilitating emotional learning. In J. S. Pelliter, R. Stern, C. Shelton, \& B. Muller-Ackerman (Eds.), Emotionally intelligent school counseling (pp. 185-199). Mahwah, NJ: Erlbaum.

Salovey, P, \& Mayer, J. D. (1990). Emotional intelligence. Imagination, cognition, and personality, 9, 185-211.

Şahin, F. T. (2006). Müzik ve hareket. E. Ömeroğlu, Ö. Ersoy, F. T. Şahin, A. Kandır ve A. Turla (Ed.), Müziğin okul öncesi dönemde kullanılması içinde (s. 79-94). Ankara: Kök.

Türnüklü, A. (2004). Okullarda sosyal ve duygusal öğrenme. Kuram ve Uygulamada Ĕ̈itim Yönetimi, 37, 136-152. 